\title{
SYNTHESIS, CHARACTERIZATION OF A NEW CARBONYLATED ZIRCONIUM METALLOCENE USING A DICHLORO-ZIRCONOCENE DERIVED FROM PARTIALLY ALKYLATED $S$-INDACENE
}

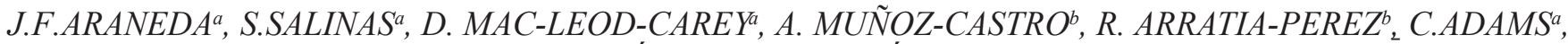 \\ I.CHÁVEZ ${ }^{a}$, J.M.MANRÍQUEZ*a.
}

\begin{abstract}
${ }^{a}$ Departamento de Química Inorgánica, Facultad de Química, Pontificia Universidad Católica de Chile. Casilla 306 Correo 22, Santiago, Chile. ${ }^{b}$ Facultad de Ecología y Recursos naturales, Universidad Andres Bello, Republica 275, Santiago, Chile.
\end{abstract} (Received: February 25, 2009 - Accepted: March 11, 2009)

\begin{abstract}
This work describes the synthesis and characterization of new organometallic species, an unprecedented mononuclear zirconium complex bearing a tetraalkylated s-indacene ligand, and secondly, its respective dicarbonyl complex obtained by reduction with $\mathrm{Mg} / \mathrm{HgCl}_{2}$. Theoretical calculations of these two compounds were carried out to gain further understanding of these novel molecular systems.
\end{abstract}

Keywords: s-indaceno, zirconium dicarbonyl,zirconocene, DFT.

\section{INTRODUCTION}

The chemistry of catalysts of zirconium metallocenes has been a thoroughly studied topic for the last 20 years, since the discovery of group IV transition metal metallocenic catalysts during the early 80 s by Brintziger ${ }^{(1)}$, Sinn and Kaminsky ${ }^{(2)}$, amongst others, allowing the scientific community to use olefin polymerization for the development of new and interesting polymeric materials $^{(3)}$ and the development of new products in organic synthesis ${ }^{(4)}$. Many reports on the catalytic effect on titanocene and zirconocene chemistry have included the correlation between structure and activity, developing single bridged $\mathrm{Cp}$ rings ${ }^{(5)}$ as well as doubly bridged metallocenes ${ }^{(6)}$. Regardless of the large number of articles devoted to the field of polymerization catalysts, many of these present expensive synthetic procedures and/or low yields ${ }^{(7)}$ as well as little information describing the electronic factors that may affect the metallic center ${ }^{(8)}$. Therefore, our group has endeavored into the synthesis of new $\mathrm{Zr}$ complexes with $s$-indacene for ligand, based on a previous work ${ }^{(9)}$ which reports the importance on catalytic activity to be related on the size, structure and electronic density of the ligand bonded to the metallic center, these facts strongly influence the activity and stereospecificity of olefin polymerization $^{(10)}$.

Here we report the synthesis and characterization of a new series of zirconium precatalysts using 2,6-diethyl-4,8-dimethyl-1,5-dihydro-s-indacene $\left(s\right.$-Ic' $\left.\mathrm{H}_{2}\right)$ as main ligand as well as cyclopentadienyl $(\mathrm{Cp})$ as secondary ligand (See Scheme 2). The ligand 2,6-diethyl-4,8-dimethyl-1,5-dihydro-s-indacene ${ }^{(11)}$ is an organic ring system with two Cp-like rings fused by a benzene ring, which once combined with a suitable base such as $\mathrm{KH}$ or $n-\mathrm{BuLi}^{(12)}$, the ligand becomes suitable to allow the entry of a metallic fragment.

Also here reported, is the characterization of the bicabonylated complex after reduction with $\mathrm{Mg}$. Previous reports indicate the use of carbonylated zirconocenes as catalysts in the hydrogenation of $\mathrm{CO}$ to $\mathrm{CH}_{3} \mathrm{OH}^{(13)}$, or the hydrogenation of phenylacetylene ${ }^{(14)}$, where the partially alkylated s-indacene ligand may shed some light concerning how does a large organic ligand affect these catalytic processes, whether by steric hinderance or electronic factors. The carbonylated derivative was analyzed by DFT simulation tools in order to better understand the $v_{\mathrm{CO}}$ stretching frequency of the metal carbonyl complex, as it provides a simple means of assessing the electron density of the metallic center ${ }^{(15)}$, together with a comparison with experimental values to support these assessments.

\section{EXPERIMENTAL}

\section{General Procedures}

All manipulations were carried out under pure dinitrogen atmosphere using a vacuum atmosphere drybox equipped with a Model HE 493 DriTrain purifier or a vacuum line using standard Schlenk-tube techniques. Reagent grade solvents (THF, Hexanes) were distilled under dinitrogen from sodium benzophenone ketyl (tetrahydrofuran, toluene, petroleum ether). The starting compounds 2,6-diethyl-4,8-dimethyl-1,5-dihydro-s-indacene ${ }^{(11)}$, and $\mathrm{CpZrCl}_{3} \cdot \mathrm{DME}^{(16)}$ were prepared according to published methods. Mg powder, $\mathrm{HgCl}_{2}, \mathrm{CO} 99.0 \%, n$-Butyl-lithium $\left(1.6 \mathrm{M}\right.$ in hexanes) and $\mathrm{C}_{6} \mathrm{D}_{6}\left(\mathrm{C}_{6} \mathrm{D}_{6}\right.$ was dried with Na prior use) were purchased from Aldrich. ${ }^{1} \mathrm{H}$ and ${ }^{13} \mathrm{C}\left\{{ }^{1} \mathrm{H}\right\} \stackrel{\mathrm{N} M R}{6}$ spectra were recorded on Bruker Avance $400 \mathrm{MHz}$. Elemental analyses (C and H) were made with a Fisons EA 1108 microanalyzer.
$\mathrm{CpZrCl}_{2}$ (2,6-diethyl-4,8-dimethyl-5-hydro-s-indacene) $\quad$ (CpZrCl$\boldsymbol{s}$-Ic'H): A dissolution of $0.3 \mathrm{~g}(1.25 \mathrm{mmol})$ of 1,5-dihydro-2,6-diethyl-4,8dimethyl-s-indacene $\left(s\right.$-Ic' $\left.\mathrm{H}_{2}\right)$ in $30 \mathrm{~mL}$ of THF were cooled to $-80^{\circ} \mathrm{C}$ and $0.88 \mathrm{~mL}(1.25 \mathrm{mmol})$ of $n$-BuLi $1.6 \mathrm{M}$ were added slowly with vigorously stirring. Once the addition is complete, is left to warm to room temperature, and after $2 \mathrm{~h}$ a clear dark red solution is obtained, then the THF is evaporated. To this solid is added a solution of $\mathrm{CpZrCl}_{3} \cdot \mathrm{DME} 0.441 \mathrm{~g}(1.25 \mathrm{mmol})$ in 20 $\mathrm{mL}$ of toluene. This mixture is then refluxed by $35 \mathrm{~h}$ resulting after this time in a yellow solution which is filtered and washed twice with toluene. The solvent is evaporated obtaining a gummy yellow solid which is dissolved with hot hexane and the solution is filtered to eliminate the $\mathrm{LiCl}$ formed. This solution is then concentrated until the yellow $\mathrm{CpZrCl}_{2}-s$-Ic' $\mathrm{H}$ precipitates. The solid is then filtered off and dried under vacuum. Yield $0.32 \mathrm{~g}(55 \%)$. ${ }^{1} \mathrm{H}$ RMN $\left(\mathrm{C}_{6} \mathrm{D}_{6}\right)$ $\delta$ ppm: $0.981\left(\mathrm{t},{ }^{3} \mathrm{~J}_{\mathrm{H}-\mathrm{H}}=7.1 \mathrm{~Hz}, 3 \mathrm{H}, \mathrm{C}_{6}-\mathrm{CH}_{2}-\mathrm{CH}_{3}\right), 1.081\left(\mathrm{t},{ }^{3} \mathrm{~J}_{\mathrm{H}-\mathrm{H}}=7.3 \mathrm{~Hz}, 3 \mathrm{H}\right.$, $\left.\mathrm{C}_{2}-\mathrm{CH}_{2}-\mathrm{CH}_{3}\right), 2.150\left(\mathrm{q},{ }^{3} \mathrm{~J}_{\mathrm{H}-\mathrm{H}}=7.1 \mathrm{~Hz}, 3 \mathrm{H}, \mathrm{C}_{6}-\mathrm{CH}_{2}-\mathrm{CH}_{3}\right), 2.207\left(\mathrm{~s}, 3 \mathrm{H}, \mathrm{C}_{4}-\mathrm{CH}_{3}\right)$, $2.286\left(\mathrm{~s}, 3 \mathrm{H}, \mathrm{C}_{8}-\mathrm{CH}_{3}\right), 2.654\left(\mathrm{q},{ }^{3} \mathrm{~J}_{\mathrm{H}-\mathrm{H}}=7.3 \mathrm{~Hz}, 3 \mathrm{H}, \mathrm{C}_{2}-\mathrm{CH}_{2}-\mathrm{CH}_{3}\right),(2.791(\mathrm{~d}$, $\left.{ }^{2} \mathrm{~J}_{\mathrm{H}-\mathrm{H}}=22.4 \mathrm{~Hz}, 1 \mathrm{H}, \mathrm{C}_{5}-\mathrm{H}_{\mathrm{a}}\right), 2.910\left(\mathrm{~d},{ }^{2} \mathrm{~J}_{\mathrm{H}-\mathrm{H}}=22.4 \mathrm{~Hz}, 1 \mathrm{H}, \mathrm{C}_{5}-\mathrm{H}_{\mathrm{b}}\right), 5.810(\mathrm{~s}, 5 \mathrm{H}$, $\mathrm{Cp}), 6.011\left(\mathrm{~s}, 1 \mathrm{H}, \mathrm{C}_{1} \mathrm{H}\right), 6.148\left(\mathrm{~s}, 1 \mathrm{H}, \mathrm{C}_{3} \mathrm{H}\right), 6.435\left(\mathrm{~s}, 1 \mathrm{H}, \mathrm{C}_{7} \mathrm{H}\right) .{ }^{13} \mathrm{C} \mathrm{RMN}$ $\left(\mathrm{C}_{6} \mathrm{D}_{6}\right) \delta \mathrm{ppm}: 14.53\left(\mathrm{C}_{6}-\mathrm{CH}_{2}-\mathrm{CH}_{3}\right), 15.51\left(\mathrm{CH}_{3}-\mathrm{C}_{8}\right), 15.22\left(\mathrm{CH}_{3}-\mathrm{C}_{4}\right), 24.57$ $\left(\mathrm{C}_{2}-\mathrm{CH}_{2}-\mathrm{CH}_{3}\right), 24.82\left(\mathrm{C}_{6}-\mathrm{CH}_{2}-\mathrm{CH}_{3}\right), 39.00\left(\mathrm{C}_{5}\right), 101,32\left(\mathrm{C}_{1}\right), 103.33\left(\mathrm{C}_{3}\right)$, $112,56\left(\mathrm{C}_{6}-\mathrm{CH}_{2}-\mathrm{CH}_{3}\right), 116.08(\mathrm{Cp}), 123.49\left(\mathrm{C}_{7}\right), 125.24\left(\mathrm{C}_{4}\right), 125.82\left(\mathrm{C}_{33}\right)$, $128.08\left(\mathrm{C}_{8 \mathrm{a}}\right), 139.17\left(\mathrm{C}_{4 \mathrm{a}}\right), 141.90\left(\mathrm{C}_{2}\right), 142.54\left(\mathrm{C}_{7 \mathrm{a}}\right), 152.55\left(\mathrm{C}_{6}\right)$. (Anal. Calc $\mathrm{C}_{23} \mathrm{H}_{26} \mathrm{Cl}_{2} \mathrm{Zr}$ : C: $59.44 ; \mathrm{H}: 5.64$. Found: C: $59.76 ; \mathrm{H}: 5.89$.

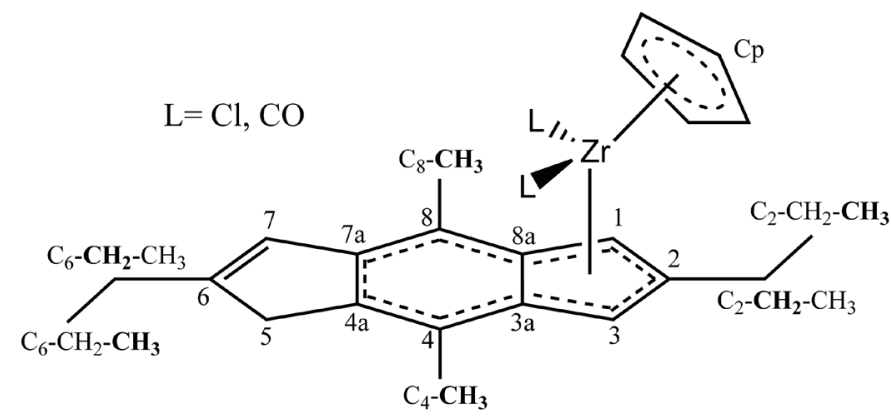

Scheme 1 : NMR assignations of the tetraalkylated $s$-indacene ligand for the here reported complexes.

$\mathrm{CpZr}(\mathrm{CO})_{2}(2,6$-diethyl-4,8-dimethyl-5-hydro-s-indacene)

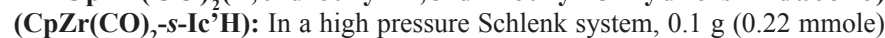
of $\mathrm{CpZrCl}_{2}-s$-Ic' $\mathrm{H}$ in $20 \mathrm{~mL}, 2.7 \mathrm{mg}$ of $\mathrm{Mg}(0,11 \mathrm{mmole})$ and $59.7 \mathrm{mg}$ of $\mathrm{HgCl}_{2}$ $(0.22$ mmole) are added to $20 \mathrm{~mL}$ of THF. This mixture is placed in a cold bath at $-80^{\circ} \mathrm{C}$. The flask was later evacuated and refilled with $1 \mathrm{~atm}$ of $\mathrm{CO}$ and then vigorously stirred for $24 \mathrm{~h}$. During this time, the yellow solution turns brownish-green. The solvent of the remaining mixture was evaporated and filtered with hexanes.

\section{Computational Details}

Theoretical calculations were made with the Amsterdam Density Functional package, ADF 2006.01(17). Structures were fully optimized (without 
any geometric constrain) by analytical energy gradient techniques employing the Local Density Approximation ${ }^{(18)}$ (LDA), and the Generalized Gradient Approximation (GGA) method using Vosko, Wilk and Nusair's local exchange correlations $^{(19)}$, with non local exchange corrections by Becke ${ }^{(20)}$, and non local electronic correlations by Perdew ${ }^{(21)}$. The uncontracted type IV basis set having Triple- $\xi$ accuracy sets of Slater-Type Orbitals ${ }^{(22)}$ (STO) with a single polarization function added for the main group elements ( $2 \mathrm{p}$ on $\mathrm{H} ; 3 \mathrm{~d}$ on $\mathrm{C}$ and $\mathrm{O} ; 4 \mathrm{~d}$ on $\mathrm{Cl}$ ) were used. Frozen Core approximation ${ }^{(23)}$ was applied to the inner orbitals of the constituent atoms: $\mathrm{C}$ and $\mathrm{O}$ core up to $1 \mathrm{~s} ; \mathrm{Cl}$ core up to $2 \mathrm{p} ; \mathrm{Zr}$ up to $4 \mathrm{p}$. The figures shown here for frontier orbitals and employ an isosurface cutoff value of 0.05 .

\section{DISCUSSIONS}

\section{Synthesis of Zirconocenes}

In order to properly produce zirconocene complexes containing an alkylated $s$-Indacene ligand, the synthetic studies began with an appropiate half sandwich compound that would undergo salt metathesis with an alkali metal salt of the alkylated $s$-Indacene ligand to generate a mixed-ligand zirconocene dichloride, as is presented in scheme 2 . As previously mentioned, in our case the chosen ligand corresponds to 2,6-diethyl-4,8-dimethyl-1,5-dihydro-sindacene $\left(\mathrm{s}-\mathrm{Ic}^{\prime} \mathrm{H}_{2}\right)$ which was monodeprotonated with a strong base as $n$-Butyllithium. The reaction of the lithiated salt $s$-Ic'HLi with $\mathrm{CpZrCl}_{3} \cdot \mathrm{DME}$ gave the desired zirconocene dichloride $\mathrm{CpZrCl}_{2}\left(\mathrm{~s}-\mathrm{Ic}{ }^{\prime} \mathrm{H}\right)$ in a moderately good yield. This compound was isolated as yellow crystalline solid from hexane.
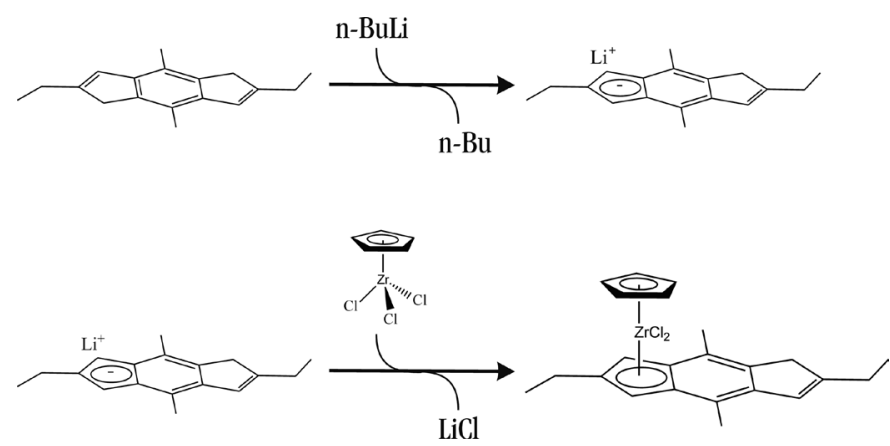

Scheme 2: Synthesis of $\mathrm{CpZrCl}_{2}$ (2,6-diethyl-4,8-dimethyl-5-hydro-sindacene)

The reduction of compound $\mathrm{CpZrCl}_{2}\left(\mathrm{~s}-\mathrm{Ic}{ }^{\prime} \mathrm{H}\right)$ was carried out with a $\mathrm{Mg} /$ $\mathrm{HgCl}_{2}$ mixture in the presence of carbon monoxide, generating the desired carbonyl complex, as presented in scheme 2 , as a brownish-green product. After repeated attempts, this product was proven to decompose at $\mathrm{CO}$ pressures lower than $1 \mathrm{~atm}$, making it impossible to have a complete characterization. The NMR analyses were inconclusive due to a rapid decomposition, however the IR spectrum (refer to Figure 4) is highly comparable to the already reported symmetric and asymmetric stretchings, together with the fact that the theoretical simulation is in good agreement with the experimental results. Also, the color of the obtained carbonyl compound is consistent with other previously reported dicarbonyl zirconocenes ${ }^{(24,32)}$. Further attempts to carry out the NMR analyses with higher pressures of $\mathrm{CO}$ have been unsuccessful due to the high complexity of the product, as well as the fact that a considerable amount of starting reagents remained in the mixture, hardening the interpretation of the resulting spectra.

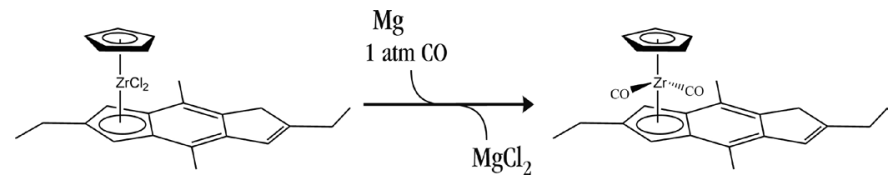

Scheme 3: Synthesis of $\mathrm{CpZr}(\mathrm{CO})_{2}$ (2,6-diethyl-4,8-dimethyl-1-hydro-sindacene)

\section{NMR Considerations}

A two-dimensional NMR study, particularly with $\mathrm{H}-\mathrm{H}$ and $\mathrm{C}-\mathrm{H}$ COSY, HMBC and Nuclear Overhauser Effect spectroscopy tools assisted us to correctly interpret the previously assigned signals in one-dimensional NMR spectra. NOESY was decisive to differentiate the methyl groups on the benzene ring, and finally, $\mathrm{HMBC}$ was fundamental to assign quaternary carbons.

Complex $\mathrm{CpZrCl}_{2}\left(s-\mathrm{Ic} \mathrm{C}^{\prime} \mathrm{H}\right)$ shows that protons 1 and 3 (see Scheme 1) appear as different signals. Also, both protons from carbon atom 5 also appear as two different signals (doubled duplet), one facing the $\mathrm{CpZrCl}_{2}$ moiety, while the other facing away from it. This spectroscopical behavior is completely different from the other mononuclear complexes of s-indacene developed by our laboratory group such as $\mathrm{Fe}, \mathrm{Ru}, \mathrm{Co}$ and $\mathrm{Rh}$ mononuclear compounds ${ }^{(25)}$. All of the latter present a singlet for both protons 1 and 3 and a broad singlet for protons 5 , possibly indicating the $\mathrm{Zr}$ complex presents a degree of rigidity possibly due to the fact that the chlorine atoms bonded to $\mathrm{Zr}$ may present a strong steric hindrance with the methyl groups on positions 4 and 8 , restricting the rotation of the metallic moiety.

It is worthwhile to remark that the structure of the compound does not correspond to the traditionally accepted by the majority of zirconium metallocenes, possibly explained to the large bulky ligand such as the tetraalkylated $s$-indacene, forcing the complex to adopt a bent and rigid structure, despite the fact that these complexes are not ansa-metallocenes. Also, this property may result as a promising feature in homogenous catalysis, particularly in the polymerization of propylene, as these catalytic systems have mostly been carried out successfully by bridged ansa-metallocenes ${ }^{(26)}$.

\section{DFT Studies}

Due to the lack of an X-ray structure of either of the products, we carried out theoretical calculations at DFT level in order to investigate the preferred coordination modes towards the $s$-Ic' ligand in both complexes. The geometry of both compounds were fully optimized without any symmetry or geometrical constrains. The Key structural parameters are given in Table 1 according to the parameters showed in Figure 1, in agreement with the following nomenclature which was defined for an idealized $\mathrm{C}_{2 \mathrm{v}}$ geometry of a bent metallocene $\mathrm{e}^{(27 \mathrm{c})}: \alpha=$ interplanar-ring angle, $\mathrm{b}=\mathrm{Cp}_{\text {norm }}-\mathrm{Cp}_{\text {norm }}$ angle $(\alpha+\beta=180), \gamma=\mathrm{Cp}_{\text {cent }}-\mathrm{Zr}-$ $\mathrm{Cp}_{\text {cent }}$ angle, $\tau=$ tilt angle $=0.5(\gamma-\beta)$, the angle between the $\mathrm{Zr}-\mathrm{Cp}_{\text {cent }}$ vector and the ring normal.

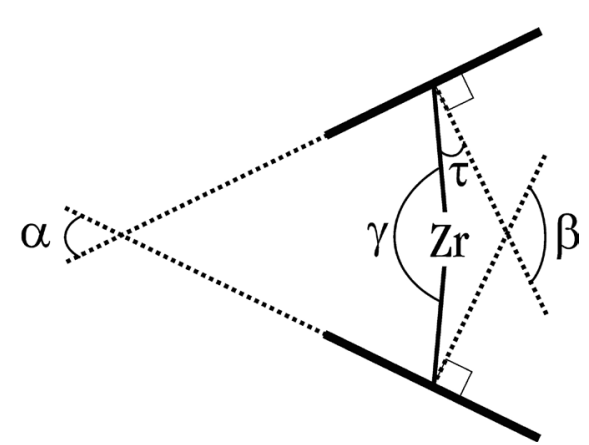

Figure 1: Parameters to define zirconocene geometry. 
Table 1: Selected Calculated distances $(\AA)$ and structural parameters (degrees).

\begin{tabular}{|c|c|c|}
\hline & {$\left[\mathrm{CpZrCl}_{2}\left(\mathrm{~s}-\mathrm{Ic}^{\prime} \mathrm{H}\right)\right]$} & {$\left[\mathrm{CpZr}(\mathrm{CO})_{2}\left(\mathrm{~s}-\mathrm{Ic} \mathrm{c}^{\prime} \mathrm{H}\right)\right]$} \\
\hline$d \mathrm{Zr}$-L average & 2.431 & 2.228 \\
\hline $\mathrm{L}-\mathrm{Zr}-\mathrm{L}$ angle & 95.53 & 88.87 \\
\hline$d \mathrm{Zr}-\mathrm{C}_{\mathrm{Cp}}$ average & 2.493 & 2.571 \\
\hline$d \mathrm{Zr}-\mathrm{C}_{\mathrm{Cp}}$ range & $2.466-2.518$ & $2.530-2.619$ \\
\hline$d \mathrm{Zr}-\mathrm{C}_{s-\mathrm{lc}}$, average & 2.530 & 2.578 \\
\hline$d \mathrm{Zr}-\mathrm{C}_{s-\mathrm{lc}}$, range & $2.463-2.613$ & $2.507-2.668$ \\
\hline$d \mathrm{Cp}_{\text {cent }}-\mathrm{Zr}$ & 2.196 & 2.267 \\
\hline$d s$-Ic ${ }_{\text {cent }}^{\prime}-\mathrm{Zr}$ & 2.229 & 2.269 \\
\hline$\alpha$ & 52 & 37 \\
\hline$\beta$ & 128 & 143 \\
\hline$\gamma$ & 130 & 144 \\
\hline
\end{tabular}

First of all, it must be noted that in $\left[\mathrm{CpZrCl}_{2}\left(s-\mathrm{Ic}{ }^{\prime} \mathrm{H}\right)\right]$, the $\mathrm{Cp}$ and the five ring member of the $s$-Ic' ligand where the $\mathrm{Zr}$ is bonded adopts a twisted staggered conformation, while in $\left[\mathrm{CpZr}(\mathrm{CO})_{2}\left(s-\mathrm{Ic}{ }^{\prime} \mathrm{H}\right)\right]$ the adopted conformation is eclipsed (refer to Figure 2). Also, in $\left[\mathrm{CpZrCl}_{2}\left(s-\mathrm{Ic}{ }^{\prime} \mathrm{H}\right)\right]$ one of the chlorine atoms is located under the six member ring of the $s$-Ic' ligand and the other chlorine atom is located pointing towards $\mathrm{C}_{3}$ of the $s$-Ic' ligand forming an $\mathrm{Cl}$ $\mathrm{Zr}-\mathrm{Cl}$ angle of $95.53^{\circ}$. In $\left[\mathrm{CpZr}(\mathrm{CO})_{2}\left(s-\mathrm{Ic}{ }^{\prime} \mathrm{H}\right)\right]$, one carbonyl ligand is located above carbon atom 4 of $s$-Ic' while the other carbonyl group is placed between carbon atoms 2 and 3 . These two ligands form an angle $88.87^{\circ}$.

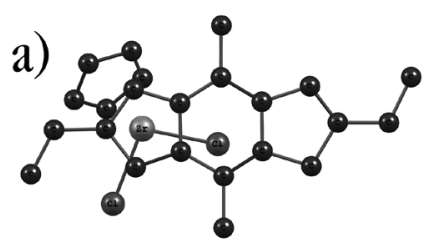

c)

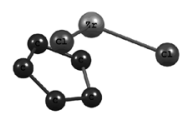

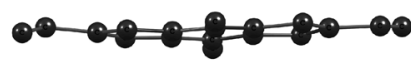

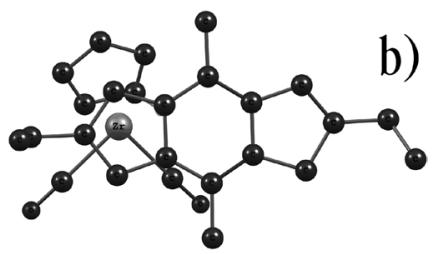

d)
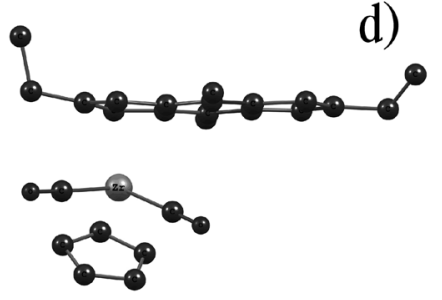

Figure 2: Images of the optimized structures of the complexes. a) View from above of $\left[\mathrm{CpZrCl}_{2}\left(s-\mathrm{Ic} c^{\prime} \mathrm{H}\right)\right]$. b) View from above of $\left[\mathrm{CpZr}(\mathrm{CO})_{2}\left(s-\mathrm{Ic} \mathrm{c}^{\prime} \mathrm{H}\right)\right]$. c) Side view of $\left[\mathrm{CpZrCl}_{2}\left(s-\mathrm{Ic} \mathrm{C}^{\prime} \mathrm{H}\right)\right]$. d) Side view of $\left[\mathrm{CpZr}(\mathrm{CO})_{2}\left(s-\mathrm{Ic}{ }^{2} \mathrm{H}\right)\right]$.

The $\mathrm{Zr}-\mathrm{Cp}$ and $\mathrm{Zr}$-s-Ic' distances are longer for complex $\left[\mathrm{CpZr}(\mathrm{CO})_{2}(s-\right.$ Ic'H)] than for its dichloro analogue. This could happen due to the eclipsed conformation the bicarbonylated complex has, creating a larger steric hindrance, increasing the distances of the organic ligands to the $\mathrm{Zr}$ atom when compared to the dichloro complex. These larger distances as well as a stable eclipsed configuration may explain the lack of rigidity noted on the ${ }^{1} \mathrm{H}-\mathrm{NMR}$ spectrum, as previously mentioned.
The interplanar ring angle $(\alpha)$ is smaller for the dichloro complex than for the bicarbonyl complex. Simultaneously, $\beta$ is larger for the latter complex. This is clearly indicative that the complex with CO ligands has a greater value of bite angle, possibly due to the repulsion produced by the eclipsed conformation of Cp with $s$-Ic', as previously explained.
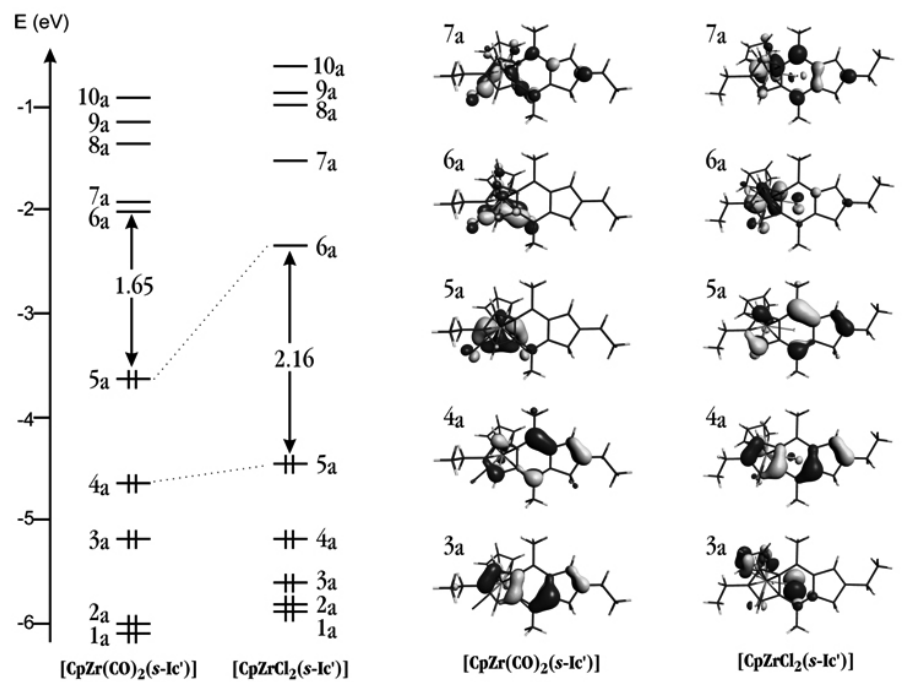

Figure 3: MO diagram and frontier orbitals of $\left[\mathrm{CpZrCl}_{2}\left(s-\mathrm{Ic} \mathrm{c}^{\prime}\right)\right]$ and $\left[\mathrm{CpZr}(\mathrm{CO})_{2}\left(s-\mathrm{Ic} c^{\prime}\right)\right]$ complexes

The electronic structure of a bent zirconocene has been well known for decades $^{(27)}$. Also the bonding modes of the indacene complexes are known ${ }^{(28)}$. Nevertheless, the electronic structure of $s$-Indacene zirconium complexes has not been yet studied, may be due to the fact that it had never been previously synthetized.

As depicted from Figure 1, [ $\mathrm{CpZrCl}_{2}(s$-Ic')] exhibits a large HOMOLUMO gap, which explains the high stability of the synthetized dichloro zirconocene. The reduction of the HOMO-LUMO gap from $2.16 \mathrm{eV}$ to $1.65 \mathrm{eV}$ is due to backbonding interactions with the $\mathrm{CO}$ group, as well as a reduction of the stability of the carbonyl product. It is $\mathrm{known}^{(27 \mathrm{c})}$ that the key orbital in determining both, the electron affinity of $\left[\mathrm{CpZrCl}_{2}\left(s-\mathrm{Ic}{ }^{\prime} \mathrm{H}\right)\right]$ and the $v_{\mathrm{Co}}$ of $\left[\mathrm{CpZr}(\mathrm{CO})_{2}\left(s-\mathrm{Ic} c^{\prime} \mathrm{H}\right)\right]$ are the $6 \mathrm{a}$ and $5 \mathrm{a}$ orbitals in $\left[\mathrm{CpZrCl}_{2}\left(s-\mathrm{Ic} \mathrm{c}^{\prime} \mathrm{H}\right)\right]$ and $\left[\mathrm{CpZr}(\mathrm{CO})_{2}\left(s-\mathrm{Ic} c^{\prime} \mathrm{H}\right)\right]$ respectively.

The $6 \mathrm{a}$ orbital of $\left[\mathrm{CpZrCl}_{2}(s\right.$-Ic'H)] is unnocupied, and corresponds to LUMO, with a corresponding eigenvalue of $-2.32 \mathrm{eV}$, which can be compared to the calculated values by $\mathrm{Zachmanoglou}\left({ }^{(27 \mathrm{c})}\right.$ for $\left[\mathrm{Cp}_{2} \mathrm{ZrCl}_{2}\right](-2.77 \mathrm{eV})$ and $\left[\mathrm{Cp}^{*} \mathrm{ZrCl}_{2}\right](-2.21 \mathrm{eV})$, indicative that $s$-Ic' ligand exerts an inductive effect over the $\mathrm{Zr}$ atom, thus increasing the electrondensity over it. This orbital presents a large $d$ character as is expected, having an antibonding interaction with the two $\mathrm{Cl}$ atoms and also it must be noted the bonding character of the interaction with the $\mathrm{Cp}$ and $s$-Ic' ligands.

In $\left[\mathrm{CpZr}(\mathrm{CO})_{2}(s\right.$-Ic'H)] complex, 5a corresponds to the $6 \mathrm{a}$ orbital of $\left[\mathrm{CpZrCl}_{2}\left(s-\mathrm{Ic}^{\prime} \mathrm{H}\right)\right]$ in which two electrons were added. Here the $\mathrm{Zr}-(\mathrm{CO})_{2}$ interaction is a bonding one mainly composed by $\mathrm{Zr} d$ and $\pi^{*}$ orbitals. It must be noted that the $\mathrm{Cp}$ and $s$-Ic' participation is reduced compared to the $6 \mathrm{a}$ in $\left[\mathrm{CpZrCl}_{2}(s-\mathrm{Ic}\right.$ 'H $\left.)\right]$ because a preferential strong back-donation to the $\pi^{*}$ orbitals of the two $\mathrm{CO}$ groups. The $5 \mathrm{a}$ and $4 \mathrm{a}$ orbitals in $\left[\mathrm{CpZrCl}_{2}\left(s-\mathrm{Ic}{ }^{\prime} \mathrm{H}\right)\right]$ which are correlated to $4 \mathrm{a}$ and $3 \mathrm{a}$ in $\left[\mathrm{CpZr}(\mathrm{CO})_{2}\left(s-\mathrm{Ic} \mathrm{c}^{\prime} \mathrm{H}\right)\right]$, presents a high participation of the $\pi$ orbitals of $s$-Ic' and a reduced participation of the $\mathrm{Zr} d$ orbitals, compared to the already analized orbitals, and an almost inexistent contribution from the $\mathrm{Cp}$ ligand. From this we thought that the conjugation over the $s$-Ic' ligand plays an important role on the bonding characteristics in these zirconium complexes and may act as a non spectator ligand during a catalytic cycle. 


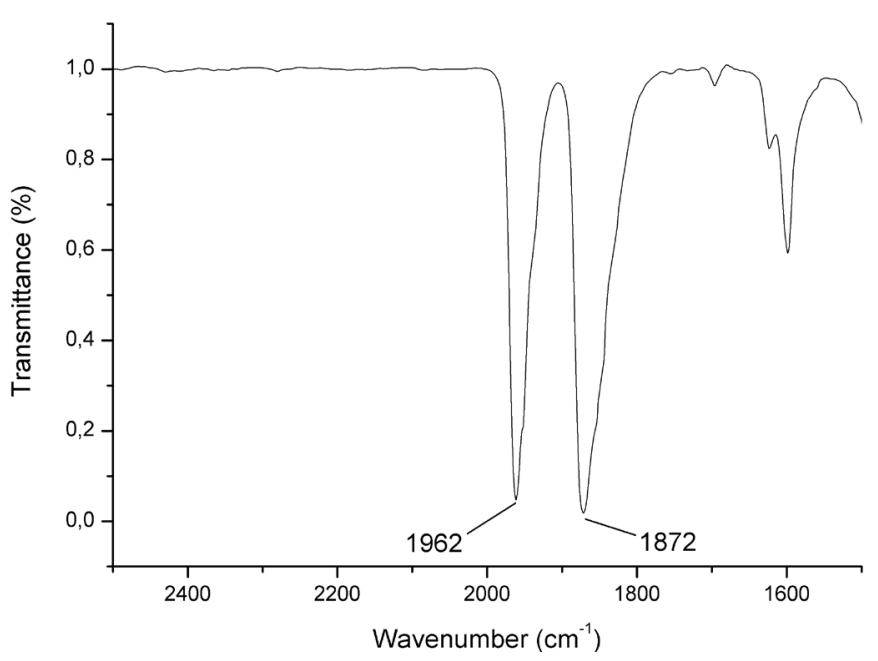

Figure 4: FT-IR Spectrum of the carbonyl stretching zone for complex $\left[\mathrm{CpZr}(\mathrm{CO})_{2}\left(s-\mathrm{Ic} c^{\prime}\right)\right]$

Table 2: Carbonyl stretching frequencies of Zirconocene Dicarbonyl complexes.

\begin{tabular}{|c|c|c|c|c|}
\hline \multirow{2}{*}{ Compound } & \multirow{2}{*}{ Reference } & \multicolumn{3}{|c|}{$v_{\mathrm{CO}}\left(\mathrm{cm}^{-1}\right)$} \\
\hline & & $v_{\mathrm{CO}(\mathrm{sym})}$ & $v_{\mathrm{CO}(\text { asym) }}$ & $v_{\mathrm{CO}(\mathrm{av})}^{\mathrm{a}}$ \\
\hline$\left[\mathrm{CpZr}(\mathrm{CO})_{2}\left(s-\mathrm{Ic} \mathrm{c}^{\prime}\right)\right]$ & This article & $\begin{array}{c}1962 \\
(1921) \\
\end{array}$ & $\begin{array}{c}1872 \\
(1864)\end{array}$ & 1917.0 \\
\hline$\left[\mathrm{Cp}_{2} \mathrm{Zr}(\mathrm{CO})_{2}\right]$ & 29 & 1976 & 1888 & 1932.0 \\
\hline$\left[\mathrm{Cp}_{2}{ }_{2} \mathrm{Zr}(\mathrm{CO})_{2}\right]$ & 30 & 1946 & 1853 & 1899.5 \\
\hline$\left[\mathrm{CpCp} * \mathrm{Zr}(\mathrm{CO})_{2}\right]$ & 31 & 1965 & 1875 & 1920.0 \\
\hline$\left[\operatorname{Ind}_{2} \mathrm{Zr}(\mathrm{CO})_{2}\right]$ & 32 & 1985 & 1899 & 1942.0 \\
\hline$\left[\mathrm{Cp}\right.$ 'IndZr(CO) $\left.{ }_{2}\right]$ & 33 & 1972 & 1888 & 1930.0 \\
\hline$\left[\mathrm{Cp}\right.$ "Ind* $\left.\mathrm{Zr}(\mathrm{CO})_{2}\right]$ & 33 & 1953 & 1865 & 1909.0 \\
\hline$\left[\mathrm{Cp} " \mathrm{Flu} * \mathrm{Zr}(\mathrm{CO})_{2}\right]$ & 33 & 1950 & 1864 & 1907.0 \\
\hline
\end{tabular}

$\mathrm{Cp}$ ' $=1,3-\left(\mathrm{SiMe}_{3}\right)_{2} \mathrm{C}_{5} \mathrm{H}_{3}, \mathrm{Cp}^{*}=\mathrm{C}_{5}\left(\mathrm{CH}_{3}\right)_{5}, \mathrm{Ind}=\mathrm{C}_{9} \mathrm{H}_{7}$,

Ind $*=\mathrm{C}_{9}\left(\mathrm{CH}_{3}\right)_{7}, \mathrm{Flu}^{*} * \mathrm{C}_{13}\left(\mathrm{CH}_{3}\right)_{9}$

a: $v_{\text {cove }}$ corresponds to the average of the symmetrical and asymmetrical stretching frequencies.

$\mathrm{b}$ : Calculated values are given in parenthesis

c: free $v_{\mathrm{CO}}=2143 \mathrm{~cm}^{-1}$.

Due to the different sensitivities of $v_{\mathrm{CO}(\mathrm{sym})}$ and $v_{\text {CO(asym) }}$ to the substitution of the ancillary ligands, the average value $v_{\text {Co(av) }}$ is employed for comparison purposes to describe the electronic influence of the substitution of the ancillary ligands.

The values of $v_{\mathrm{CO}(\mathrm{sym})}, v_{\mathrm{CO}(\text { assm) }}$ and $v_{\mathrm{CO}(\mathrm{av})}$ for several zirconocene complexes are presented in Table 1. It can be noted that when the ancillary ligands are subsequently alkylated a decreasing of the $v_{\mathrm{CO}(a v)}$ is observed. This can be explained as there is an increase of the electron density over the $\mathrm{Zr}$ atom when the ancillary ligands are alkylated, thus increasing the backbonding over the $\pi^{*}$ orbitals of the CO ligands which in turn results in the decreasing of the $v$. The same behaviour is observed when fused-ring ancillary ligands are employed. It must be noted that the employment of peralkylated species produces a greater effect than the non alkylated ones. In our case the employment of tetraalkylated $s$-Ic' could be enhanced by the employment of the peralkylated $s-\mathrm{Ic}^{*(34)}$ in order to obtain a zirconocene complex with higher electron density over the $\mathrm{Zr}$ atom.

\section{CONCLUSIONS}

We have synthesized and fully characterized the first dichloro-zirconocene derived from tetraalkylated $s$-indacene. Also, its dicarbonyl derivative was also synthesized, though its stability impaired us from achieving a complete characterization. Future attempts of synthesizing different carbonylated zirconocenes shall be carried out using ligands with a larger number of alkyl substituents, which may increase the stability of the final product.

The theoretical simulations of the dichloro complex also proved this molecular system may be suitable for the polymerization of olefins due to the observed rigidity of the $\mathrm{CpZrCl}_{2}$ moiety when bonded to $s$-Ic' $\mathrm{H}$. These studies shall be further elaborated for a future work.

\section{ACKNOWLEDGEMENTS}

Our acknowledgments go to FONDECYT Chile, Project numbers 1060589, 169588, 1070345; Apoyo de Tesis Doctoral (Projects) 23070215, 24080034. Ph.D Scolarship CONICYT. ECOS-CONICYT and FQM-UNABDI-02-09/R, UNAB-DI-09-09/I.

\section{REFERENCES}

1 (a) Wild F.R.W.P., Zsolnai L., Hutter G., Brintzinger H., J. Organomet. Chem., 232, 233, (1982). (b) Andresen A., Cordes H.G., Herwing J., Kaminsky W., Merck A., Mottweiler R., Pein J., Sinn H., Wollmer H.J., Angew. Chem., 88, 688, (1976).

2 (a) Sinn H., Kaminsky W., Adv. Organomet. Chem., 18, 99, (1980). (b) Shiono T., Mahmud A., Ikeda T., Macromolecules, 32, 5723, (1999).

3 (a) Brintzinger H., Fischer D., Mûlhaupt R., Rieger B., Waymuth R., Angew. Chem. Int. Ed. Engl., 34, 1143, (1995). (b) Kaminsky W., Steiger R., Polyhedron, 7, 2375, (1988). (c) Kaminsky W., J. Chem. Dalton Trans., 1413, (1998). (d) Coates G.W., Chem. Rev., 100, 1223, (2000). (e) Brintzinger H., Fischer D., Mülhaupt R., Rieger B., Waymont R., Angew. Chem. Int. Ed. Engl., 107, 1255, (1995). (f) Resconi L., Cevallo L., Fait A., Piemontesi F., Chem. Rev., 100, 1253, (2000). (g) Bochmann M., J. Organomet. Chem., 689, 3982, (2004). (h) F. M. Rabagliatti, C. J. Caro, M. A. Perez, Bol. Soc. Chil. Quim., 47, 137, (2002).

4 (a) S.L. Buchwald, R.D. Broene, Comprehensive Organometallic Chemistry II; E.W. Abel, F.G. Stone, G. Wilkinson, Pergamon: Elmsford, NY, Vol.12, pags 771-784. (b) E. Negishi, T. Takahashi, Synthesis, 1-19, (1988). (c) A. H. Hoveyda, J. P. Morken, Angew. Chem. Int. Ed. Engl., 35, 1262, (1996).

5 (a) H. Sinn, W. Kaminsky, Adv. Organomet. Chem., 18, 99, (1980). (b) H.H. Brintzinger, D. Fischer, R. Mülhaupt, B. Rieger, R.M. Waymouth, Angew. Chem. Int. Ed. Engl., 34, 1143, (1995). (c) G.J.P. Britovsek, V.C. Gibson, D.F. Wass, Angew. Chem. Int. Ed. Engl., 38, 428, (1999). (d) H.G. Alt, A. Koppl, Chem. Rev., 100, 1205, (2000). (e) U. Siemeling, Chem. Rev., 100, 1495, (2000). (f) H. Butenschon, Chem. Rev., 100, 1527, (2000). (g) G.W. Coates, Chem. Rev., 100, 1223, (2000). (h) J. L. Guevara, R. Quijada, P. Saavedra, H. Palza, G. B. Galland, Bol. Soc. Chil. Quim., 47, $081(2002)$

6 S. Xu, X. Dai, T. Wu, B. Wang, X. Zhou, L. Weng, J. Organomet. Chem., $\mathbf{6 4 5}, 212,(2002)$ and references therein.

7 M. Schilling, C. Görl, H. G. Alt, Applied Catalysis A: General, 348, 79, (2008) and references therein.

8 (a) C. Janiak, Metallocenes: Synthesis, Reactivity, Applications; A. Togni, R. Halterman, Wiley-VCH: Weinheim, Germany, Vol. 2, pags 576, (1998). (b) C. E. Zachmanoglou, A. Docrat, B. M. Bridgewater, G. Parkin, C. G. Brandow, J. E. Bercaw, C. N. Jardine, M. Lyall, J. C. Green, J. B. Keister, J. Am. Chem. Soc., 124, 9525, (2002).

9 C. J. Price, H. Chen, L. M. Launer, S. A. Miller, Angew. Chem. Int. Ed., 47, $1,(2008)$.

10 M. Harada, T. Mise, S. Miya, H. Yamazaki, Eur. Pat. Appl. EP0283739, (1988).

11 Darouch M., Jara P., Mendez L., Portilla Y., Abril D., Alfonso G., Chavez I., Manríquez J.M.,Riviére -Baudet M., Riviére P., Castel A., Rouzaud J., Gornitzka H., Organometallics, 20, 5591, (2001).

12 Barlow S., Cary D. R., Drewitt M., O'Hare D., J. Chem. Soc. Dalton Trans., 3867, (1997).

13 (a) L. I. Shoer, J. Schwartz, J. Am. Chem. Soc., 97, 5831, (1977). (b) J. C. Huffman, J. G. Stone, W. C. Krusell, and K. G. Caulton, J. Am. Chem. Soc., 99, 5829, (1977). (c) C. Masters, Advances in Organometallic Chemistry, Volume 17, Catalysis and Organic Synthesis, p 66. 
14 J. L. Thomas, K. T. Brown, J. Organomet. Chem., 111, 297, (1976).

15 (a) D.M.P. Mingos, Comprehensive Organometallic Chemistry; G. Wilkinson, F.G. Stone, E.W. Abel, Pergamon Press: Oxford, U.K., Vol.3, sección 19.2., (1982). (b) J. P. Collman, L. S. Hegedus, J. R. Finkem, Principles and Applications of Organotransition Metal Chemistry, University Science Books; Mill Valley, California, (1987). (c) C. Elschenbroich, A. Salzer, Organometallics, $2^{\text {nd }}$ ed; VCH; New York, (1992). (d) R. L. DeKock, A. C. Sarapu, R. F. Fenske, Inorg. Chem., 10, 38, (1971). (e) M. B. Hall, R. F. Fenske, Inorg. Chem., 11, 1619, (1972). (f) A. S. Goldman, K. Krogh-Jespersen, J. Am. Chem. Soc., 118, 12159, (1996). (g) A. J. Lupinetti, S. Fau, G. Frenking, S. H. Strauss, J. Phys. Chem., 101, 9551, (1997). (h) A. J. Lupinetti, G. Frenking, S. H. Strauss, Angew. Chem. Int. Ed. Engl., 37, 2113, (1998). (i) A. J. Lupinetti, S. H. Strauss, G. Frenking, Prog. Inorg. Chem., 49, 1, (2001).

16 C. S. Kraihanzel, M. L. Losee, J. Am. Chem. Soc., 1968, 90, 4701.

17 Amsterdam Density Functional (ADF) code, release 2007, Vrije Universiteit, Ámsterdam, The Netherlands. http://www.scm.com

18 W. Kohn, L.J. Sham, Phys. Rev. 1965, 140, A1133.

19 S.H. Vosko, L. Wilk, M. Nusair, Can. J. Phys. 1990, 58, 1200.

20 A.D. Becke, Phys. Rev. A., 38, 3098, (1988).

21 J.P. Perdew, Phys. Rev. B., 33, 8822, (1986).

22 J.G. Snijder, E.J. Baerends, P. Vernooijs, At. Nucl. Data Tables., 26, 483, (1982).

23 E.J. Baerends, D.E. Ellis, P. Ros, Chem. Phys., 2, 41, (1973).

24 A. Antiñolo, M.F. Lappert, D.J.W. Winterborn, J. Organomet. Chem., 272, 37, (1984).

25 (a) C. Adams, C. Morales-Verdejo, V. Morales, D. MacLeod-Carey, J. M. Manriquez, I. Chavez, A. Muñoz-Castro, F. Delpech, A. Castel, H. Gornitzka, M. Riviere-Baudet, P. Riviere, Eur. J. Inorg. Chem., 6, 784, (2009). (b) E. Esponda, C. Adams, F. Burgos, I. Chavez, J. M. Manriquez, F. Delpech, A. Castel, H. Gornitzka, M. Riviere-Baudet, P. Riviere, J. Organomet. Chem., 691, 3011, (2006).
26 (a) N. Iwama, H. Uchino, Y. T. Osano, T. Sugano, Organometallics, 23 , 3267, (2004). (b) L. Resconi, F. Piemontesi, I. Camurati, O. Sudmeijer, I. E. Nifant'ev, P. V. Ivchenko, L. G. Kuz'mina, J. Am. Chem. Soc., 120, 2308, (1998)

27 (a) J. W. Lauher, R. Hoffmann, J. Am. Chem. Soc., 98, 1729, (1976). (b) J. C. Green, M. L. H. Green, C. K. Prout, J. Chem. Soc. Chem. Commun., 421, (1972). (c) C. E. Zachmanoglou, A. Docrat, B. M. Bridgewater, G. Parkin, C. G. Brandow, J. E. Bercaw, C. N. Jardine, M. Lyall, J.C. Green, J.B. Keister, J. Am. Chem. Soc., 124, 9525, (2002).

28 a) M. T. Garland, J. Y. Saillard, I. Chávez, B. Oëlckers, J. M. Manríquez, J. Molecular Structure (THEOCHEM), 390, 199, (1997). b) P. Roussel, D. R. Cary, S. Barlow, J.C. Green, F. Varret, D. O'Hare, Organometallics, 19, 1071, (2000).

29 (a) G. Fachinetti, G. Fochi, C. J. Floriani, J. Chem. Soc. Chem. Commun., 1976, 230. (b) J. L. Atwood, R. D. Rogers, W. E. Hunter, C. Floriani, G. Fachinetti, A. Chiesvilla, Inorg. Chem., 19, 3812, (1980).

30 J.M. Manríquez, J.E. Bercaw, J. Am. Chem. Soc., 76, 6229, (1974).

31 P.T. Wolczanski, J.E. Bercaw, Organometallics, 1, 793, (1982).

32 (a) M.D. Rausch, K.J. Moriarty, J.L. Atwood, W.E. Hunter, E. Samuel, J. Organomet. Chem., 327, 39, (1987). (b) E. Samuel, R. Setton, J. Organomet. Chem., 42, 123, (1972).

33 P. Bazinet, T.D. Tilley, Organometallics, 27, 1267, (2008).

34 S. Barlow, D. O'Hare, Organometallics, 15, 3483, (1996). 